\title{
Emprego da gastronomia como ferramenta para promover a aceitação de verduras por crianças com excesso de peso
}

Virgínia Souza Santos, Letícia Maria de Melo, Cíntia Tavares Carleto, Martha Elisa Ferreira de Almeida, Thaís Amanda Teixeira Augusto, Leila Aparecida Kauchakje Pedrosa

\begin{abstract}
Resumo
A infância é uma das fases mais importantes para o estabelecimento de hábitos saudáveis. De acordo com a pesquisa do Sistema de Vigilância Alimentar e Nutricional (SISVAN) realizada em 2008 com 26.000 crianças e adolescentes, o consumo de verduras mostrou-se inadequado, uma vez que mais de $30 \%$ dos avaliados relataram não consumir estes alimentos durante a semana. O emprego de técnicas gastronômicas pode tornar o ato de comer um motivo de grande prazer, buscando o bem-estar e a saúde das pessoas. Avaliar a influência da gastronomia na aceitação de verduras por crianças com excesso de peso. Participaram da pesquisa 25 crianças, com idade entre 7 a 9 anos, sendo $60 \%(\mathrm{n}=15)$ do gênero feminino, matriculadas em uma escola pública de Rio Paranaíba, MG, diagnosticadas com excesso de peso, cujos pais autorizaram a participação mediante a assinatura do Termo de Consentimento Livre e Esclarecido. Aplicou-se um questionário de frequência do consumo de verduras entre as crianças, e posteriormente utilizou-se o teste de análise sensorial de aceitação através da escala hedônica facial de cinco pontos. Foram selecionadas três tipos de verduras: a abobrinha caipira, o chuchu e a beterraba. Os alimentos foram servidos durante dois momentos. Primeiramente eles foram apresentados na sua forma habitual de consumo, corte maceidoine e soufflé. Após 15 dias, os mesmos alimentos foram oferecidos com o emprego de técnicas gastronômicas, adotando as seguintes formas: chuchu - peixes; abobrinha caipira - sol; beterraba - flor. Para a análise dos dados foi aplicado o teste Wilcoxon e o Qui-quadrado. Ambos os testes foram realizados a 5\% de significância no software Statistical Package for the Social Sciences - SPSS, versão 20.0. O estudo foi aprovado pelo Comitê de Ética em Pesquisa da Universidade Federal de Viçosa, protocolo no 473.739. Ao avaliar o consumo das verduras, percebeu-se que $28 \%$ $(n=7)$ das crianças não consumiam abobrinha, $44 \%(n=11)$ e $40 \%(n=10)$ não ingeriam chuchu e beterraba, respectivamente. As notas atribuídas para as verduras aumentaram após a utilização das técnicas gastronômicas, apontando que a metodologia foi eficaz para melhorar a aceitação. Entretanto, não foram observadas diferenças estatísticas entre as pontuações. $\mathrm{O}$ gênero apresentou associação com as notas atribuídas para o chuchu após o emprego da gastronomia. A idade não demonstrou associação com as notas conferidas a nenhum alimento. Já o consumo alimentar foi associado às pontuações obtidas pela abobrinha caipira (antes) e a beterraba (depois) da aplicação das técnicas. A frequência de consumo das verduras entre as crianças avaliadas foi baixa. As notas atribuídas às verduras após a aplicação da gastronomia foram maiores do que aquelas conferidas aos alimentos oferecidos em suas formas habituais de consumo.
\end{abstract}

Descritores: Gastronomia; Análise sensorial; Verduras. 